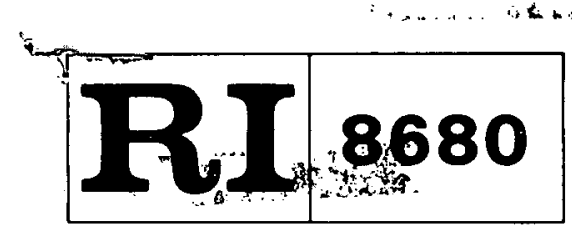

Bureau of Mines Report of Investigations/1982

\title{
MASTP
}

\section{Operation of a Mineral Recovery Unit on Brine From the Salton Sea Known Geothermal Resource Area}

\author{
By L. E. Schultze and D. J. Bauer
}

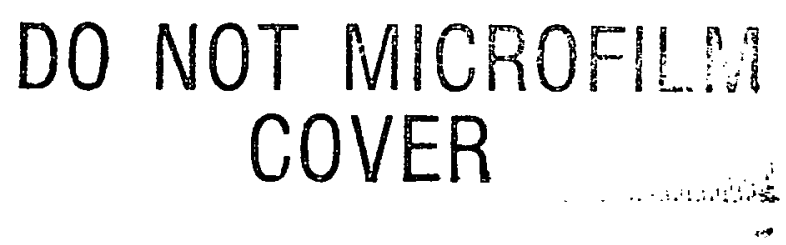

UNITED STATES DEPARTMENT OF THE INTERIOR 


\section{DISCLAIMER}

This report was prepared as an account of work sponsored by an agency of the United States Government. Neither the United States Government nor any agency Thereof, nor any of their employees, makes any warranty, express or implied, or assumes any legal liability or responsibility for the accuracy, completeness, or usefulness of any information, apparatus, product, or process disclosed, or represents that its use would not infringe privately owned rights. Reference herein to any specific commercial product, process, or service by trade name, trademark, manufacturer, or otherwise does not necessarily constitute or imply its endorsement, recommendation, or favoring by the United States Government or any agency thereof. The views and opinions of authors expressed herein do not necessarily state or reflect those of the United States Government or any agency thereof. 


\section{DISCLAIMER}

Portions of this document may be illegible in electronic image products. Images are produced from the best available original document. 
Report of Investigations $\mathbf{8 6 8 0}$

\section{Operation of a Mineral-Recovery Unit on Brine From the Salton Sea Known Geothermal Resource Area}

By L. E. Schultze and D. J. Bauer 951,1610

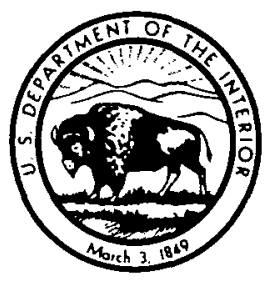

UNITED STATES DEPARTMENT OF THE INTERIOR

James G. Watt, Secretary

BUREAU OF MINES

Robert C. Horton, Director

DISTRIBUTON OF THIS BOCUMENT IS UHLLITHED 
This publication has been cataloged as follows:

Schultze, L. E. (Lawrence E.)

Operation of a mineral recovery unit on brine from the Salton Sea known geothermal resource area.

(Bureau of Mines report of investigations ; 8680)

Bibliography: p. 12.

Supt. of Docs. no.: I 28.23:8680.

1. Mineral resources in submerged lands-California-Salton Sea. 2. Geothermal resources-California-Salton Sea. 3. Metallurgy. I. Bauer, D. J. (Donald J.). II. Title. III. Series: Report of inves* tigations (United States. Bureau of Mines) ; 8680.

TN264.S35 $622^{\prime} .34 \quad 82-600150 \quad$ AACR2 


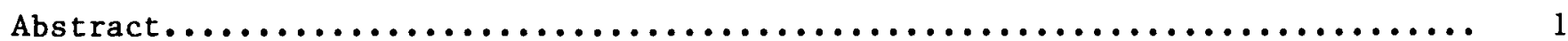

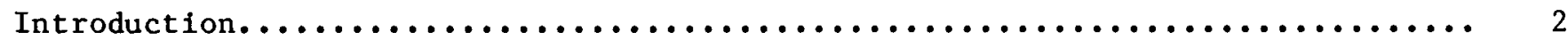

Acknowledgments ..............................................

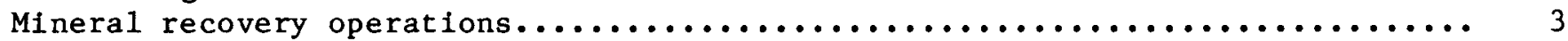

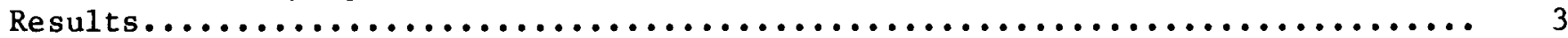

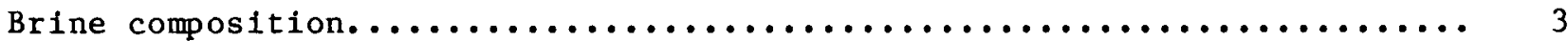

Precipitation using lime slurry with $\mathrm{pH}$ control................... 4

Precipitation of dissolved metals..........................4

Removal of precipitates.................................

Precipitation using set lime slurry addition rates....................

Lime addition rates...................................

Precipitation of dissolved metals.......................... 6

pH measurements....................................... 6

Thickener performance................................. 6

Filter cake compositions................................ 7

Silica removal....................................... 7

Precipitation using dry 1 ime.................................

Preclpitation using 1ime slurry with air injection. ................

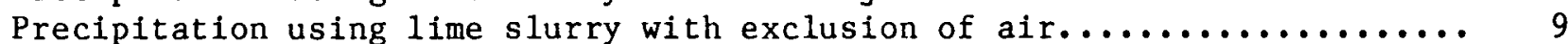

Recovery of metal values from hydroxide precipitates...................

Discussion and conclusions................................... $\ldots$

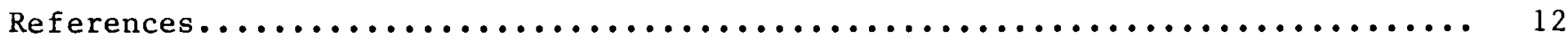

\section{ILLUSTRATIONS}

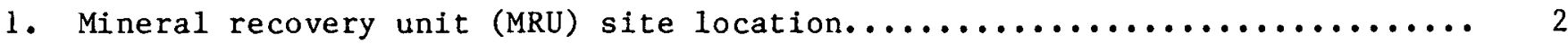

2. Flowsheet for hydroxide precipitation of metal values from brine........ 4

3. Metals precipitation versus plant operation time: lime slurry addition

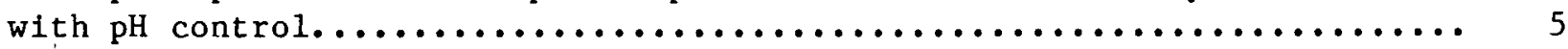

4. Percent precipitation of metals at different lime addition rates versus

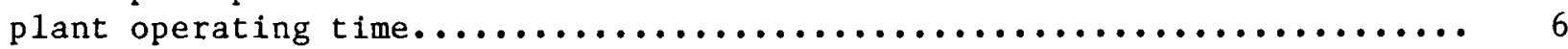

\section{TABLES}

1. Concentrations of selected components in a typical brine sample..........

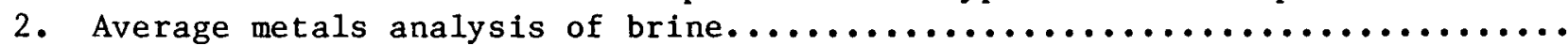

3. Metals analysis of typical hydroxide filter cake obtained during test $1 . .$.

4. Analyses of metals in hydroxide filter cakes......................

5. Metals composition of solids produced by addition of dry lime...........

6. Metal concentration ratios in brine and filtered hydroxides.............

7. Metals analysis of hydroxide filter cake prepared for recovery studies.....

8. Gross value of metals precipitated from post-flash brines.............. 
OPERATION OF A MINERAL RECOVERY UNIT ON BRINE FROM THE SALTON SEA KNOWN GEOTHERMAL RESOURCE AREA

By L. E. Schultze ${ }^{1}$ and D. J. Baver ${ }^{2}$

\section{ABSTRACT}

The Bureau of Mines operated a mineral recovery unit to recover metal values from post-flash geothermal brines from the Salton Sea known geothermal resource area as part of its research into the use of plentiful resources. The brine was available for metals recovery after its heat content had been used to generate electricity. The brine source was treated with lime to precipitate the contained iron, manganese, lead, and zinc before injection of the heat-depleted brine into the underground reservoir. Data are presented on the effects of process variables, such as rate and method of lime addition and air oxidation versus air exclusion. Variations in precipitation of metal values, composition of precipitates, effectiveness of slurry thickeners, and methods of treating the precipitates to recover metal values are discussed.

\footnotetext{
${ }_{1}$ Research chemist.

${ }^{2}$ Supervisory chemical engineer. Both authors are with the Reno Research Center, Bureau of Mines, Reno, Nev. $9 5 1 \longdiv { 1 6 1 0 }$
} 


\section{INTRODUCTION}

The past few years have witnessed an increasing interest in developing underutilized energy resources to relieve the pressure on petroleum imports. A potential energy source under investigation $(7)^{3}$ is geothermal brine from the Salton Sea known geothermal resource area (KGRA). The high temperature of these brines makes them particularly interesting for generating electricity by flashing steam from the brine. Since these high-salinity brines could represent a plentiful domestic resource of certain metal values, the Bureau of Mines became interested in investigating methods for recovering the metal and/or mineral values from these sources.

The Salton Sea KGRA brines contain 200,000 to $250,000 \mathrm{ppm}$ of total dissolved salts (6). The majority of the dissolved salts consist of $\mathrm{Na}, \mathrm{K}$, and $\mathrm{Ca}$ chlorides. There are sufficient concentrations of other metal salts to warrant consideration for recovery. If $10 \mathrm{mil1i}$. $1 \mathrm{~b} / \mathrm{hr}$ of brine are required to operate a 100-MW electrical generation station and the brine density is $9.47 \mathrm{lb} / \mathrm{ga} 1$, any dissolved metal value existing at a concentration of $100 \mathrm{mg} / 1$ ( $88 \mathrm{ppm}$ ) would represent 0.44 short ton per hour (ton/hr).

While recovery of salts from brines is we11 known and has been practiced for many years (8), certain limitations imposed by the location of the Salton Sea KGRA brines in the Imperial Valley of California preclude the use of evaporation ponds for fractional crystallization of salts and concentration of metal va1ues. Because of these limitations, the energy recovery circuit is committed to injection of spent brine into an underground reservoir. A metal recovery scheme will have to be compatible with this energy recovery circuit. The Bureau of Mines funded contract research to determine the most promising methods for recovering metal values from Salton Sea

${ }^{3}$ Underlined numbers in parentheses refer to items in the list of references at the end of this report.
KGRA brines $(1,3, \underline{3})$. The most practical approach resulting from these studies involved increasing the $\mathrm{pH}$ of the brine with lime to precipitate iron, manganese, zinc, and lead ( 1,3$)$. An engineering study was undertaken (2) to design a demonstration plant based on the lime precipitation method.

A mineral recovery unit (MRU) based essentially on the engineering design was assembled and operated on post-flash brine from the Magmamax No. 1 well near the southern end of the Salton Sea in the Imperial County of California (fig. 1). This report discusses the operation of the demonstration plant and the analyses and evaluations of the samples obtained by addition of lime.

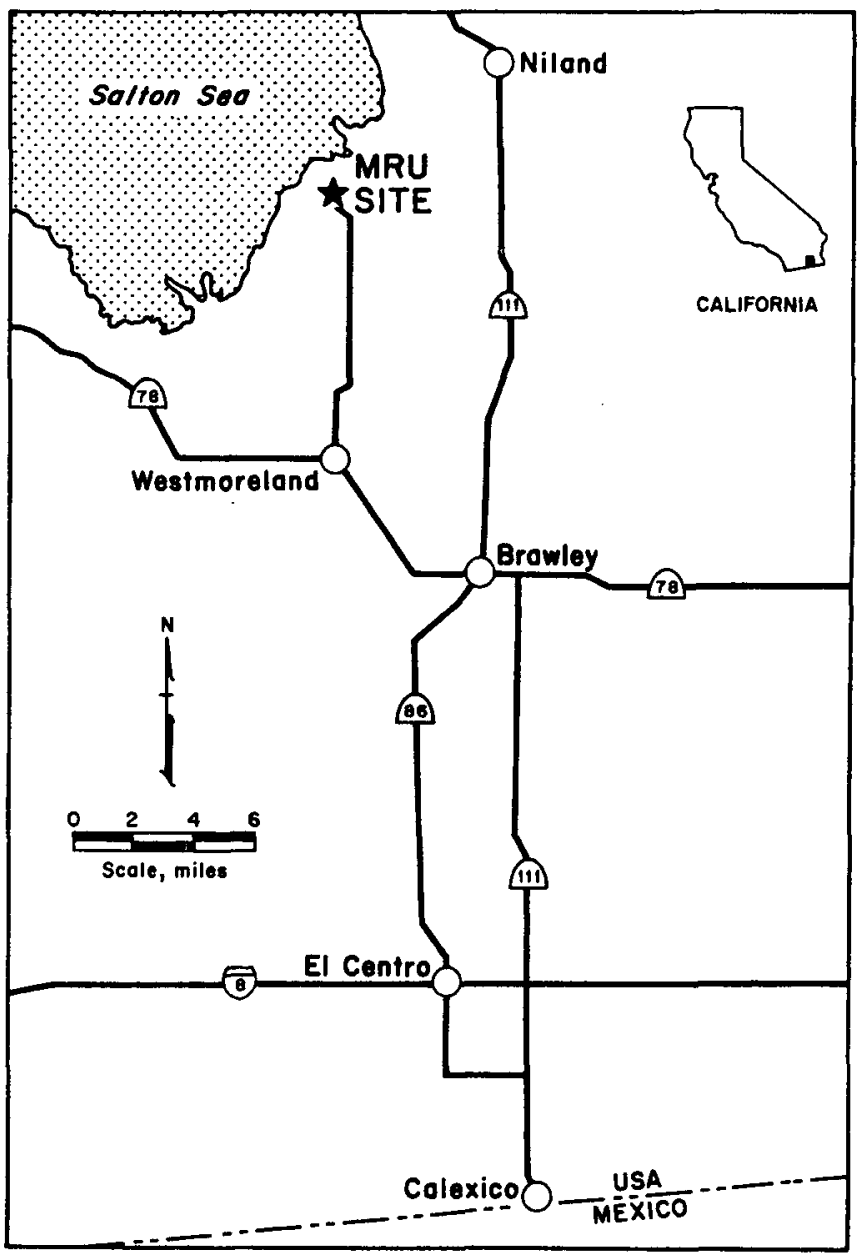

FIGURE 1. - Mineral recovery unit (MRU) site location. 


\section{ACKNOWLEDGMENTS}

The mineral recovery unit was assembled and operated by Westec Services,
Inc., under contract to the Bureau of Mines.

\section{MINERAL RECOVERY OPERATIONS}

The mineral recovery unit was assembled at the geothermal well site and designed to treat $10 \mathrm{gal} / \mathrm{min}$ of postflash geothermal brine. The MRU received brine that had been flashed to atmospheric pressure and was at a temperature of $200^{\circ}$ to $210^{\circ} \mathrm{F}$. Cooling of the brine occurred during treatment in the MRU but was minimized by insulating tanks and piping. Cooling of the brine was minimized by the ambient temperatures, which range up to $120^{\circ} \mathrm{F}$. Brine was received and held in a stirred surge tank to insure an uninterrupted flow to the MRU (fig. 2). The brine then flowed through a series of four stirred 90-gal reactors to age the brine and to permit supersaturated silica to precipitate. The silica slurry was thickened in two $5-$ by $5-\mathrm{ft}$ rake thickeners in series, and the underflow from the thickener was filtered in a 1 - by 1-ft filter press. The overflow from the silica thickener was sent to another series of four stirred 90-gal reactors for treatment with lime. The resultant slurry was fed to a 6 - by $5-f t$ rake thickener, which had been modified for maximum efficiency in thickening metal hydroxide slurries. The underflow from the hydroxide thickener was filtered in a 2- by 2-ft filter press. The overflow was treated with hydrochloric acid in a separate stirred tank to adjust the $\mathrm{pH}$ back to the value of the untreated brine ( $\mathrm{pH}$ 5.5). The acidified brine was returned to the injection line.

The MRU was operated under five sets of test conditions: precipitation using lime slurry with $\mathrm{pH}$ control (test 1), precipitation using set lime slurry addition rates (test 2), precipitation using dry lime (test 3), precipitation using lime slurry with air injection (test 4), and precipitation using lime slurry with exclusion of air (test 5 ). The results of each test and more detailed description of procedures are presented in the Results section. Comparisons between the tests are made in the Discussion and Conclusions section.

\section{RESULTS}

\section{Brine Composition}

An analysis of a typical brine sample entering the processing sequence is shown in table 1. No other metal values having concentrations more than $50 \mathrm{mg} / 1$ were detected.

\section{TABLE 1. - Concentrations of selected components in a typical brine sample, $\mathrm{mg} / 1$}

\begin{tabular}{|c|c|c|}
\hline Sodium.......... & 58,000 & Silica.......... \\
\hline Calcium...... & 25,000 & $\operatorname{Iron} \ldots \ldots \ldots \ldots$ \\
\hline Potassium....... & 12,000 & Lithium... \\
\hline Manganese....... & 680 & Barium..... \\
\hline Strontium....... & 520 & Magnesium....... \\
\hline Zinc........... & 270 & Lead............ \\
\hline Boron........... & 250 & \\
\hline
\end{tabular}




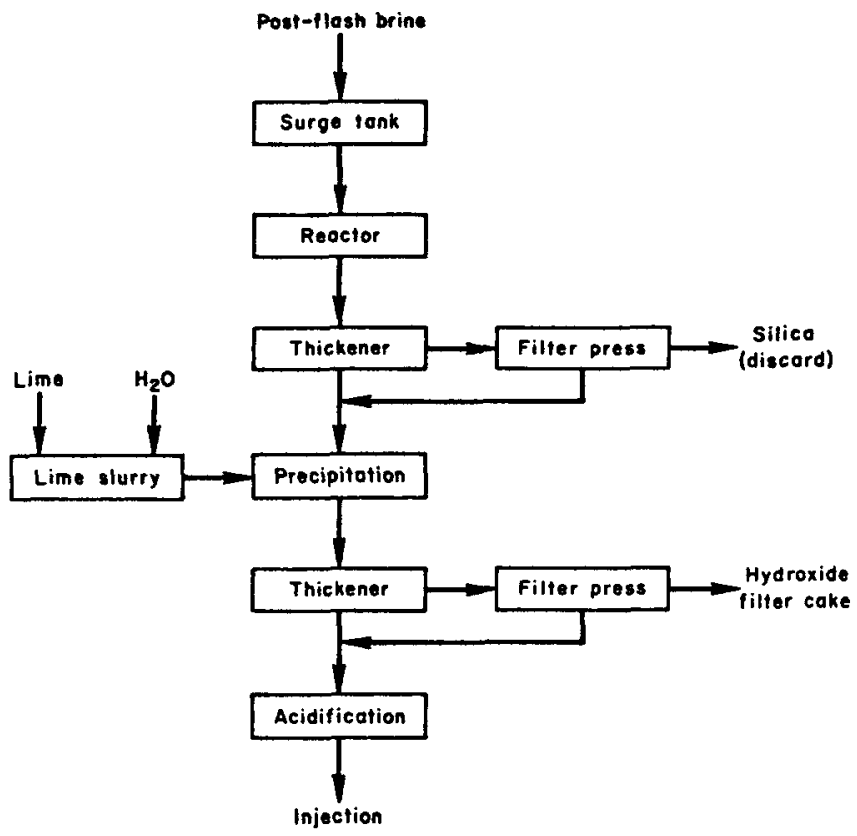

FIGURE 2. - Flowsheet for hydroxide precipitation of metal values from brine.

Samples obtained during operation of the MRU were analyzed for $\mathrm{Fe}, \mathrm{Mn}, \mathrm{Pb}$, and $\mathrm{Zn}$ because these metals represented the major components of the precipitate obtained by treatment of the brine with lime. Analyses were obtained either by inductively coupled plasma (ICP) or atomic absorption (AA). Duplicate analyses by both methods were in close agreement; the main difference was that ICP had a lower detection limit for the metals of interest. Liquid samples were submitted without further treatment. Solid samples were weighed and dissolved in a known volume of acid before analysis.

Composition of the brine was found to vary with flow rate from the production we1l. The variations were either sma11 or of short duration. An average value for brine analyses from 63 samples obtained over a period of $2-1 / 2$ months was used to calculate percent precipitation of metals. The average values are shown in table 2 .
TABLE 2. - Average metals analysis of brine, $\mathrm{mg} / 1$

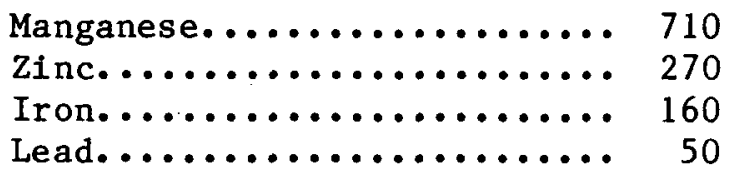

Precipitation Using Lime Slurry With $\mathrm{pH}$ Control (Test I)

Brine from the surge tank was metered with a Masoneilson,4 l-in. cam flex II valve. Since scale buildup on the valve occasionally caused diminished flow rates, the brine was periodically diverted into a 55-gal drum, and the volume collected in a given time was measured. Lime slurries were prepared by adding lime to a tank of water until the desired specific gravity was obtained. A peristaltic pump was used to pump the lime slurry into the first precipitation reactor tank.

For test l, the lime slurry was prepared at a specific gravity of 1.03 to 1.05 ( 15 pct lime). The lime slurry addition rate was adjusted to maintain a $\mathrm{pH}$ of 8.5 in the fourth reactor. During test $1, \mathrm{pH}$ readings ranged from 6.1 to 10.7. Addition rates of lime were varied from 17 to $861 \mathrm{~b} / 1,000 \mathrm{gal}$ of brine in attempts to maintain $\mathrm{pH}$ 8.5. Part of the difficulty was caused by a coating of lime and hydroxides on the electrodes. This gave $\mathrm{pH}$ readings that were not representative of the actual $\mathrm{pH}$ of the liquid portion of the slurry.

\section{Precipitation of Dissolved Metals}

Even though $\mathrm{pH}$ readings were erratic, analysis of slurry filtrates showed good precipitation of dissolved metals

${ }^{4}$ Reference to specific trade names is made for identification only and does not imply endorsement by the Bureau of Mines. 
(fig. 3). Analyses of iron and lead in the filtrates were below detection limits of $4 \mathrm{mg} / 1$ for iron and $7.5 \mathrm{mg} / 1$ for lead, corresponding to precipitations of 98 pct and 85 pct, respectively. Analyses of manganese and zinc showed that precipitation increased to 95 pct after $40 \mathrm{hr}$ of operation. Samples taken after $86 \mathrm{hr}$ of operation showed a slight decrease in precipitation of both metals. Lime addition rate at the 86-hr sample time was $21 \mathrm{lb} / 1,000$ gal of brine with a corresponding measured $\mathrm{pH}$ of 7.9. When lime addition rate was increased to raise the $\mathrm{pH}$ to the designed value of 8.5, precipitation of manganese and $z$ inc increased to more than 95 pct.

\section{Removal of Precipitates}

Thickening and filtration of the hydroxide slurries presented no major problems. Overflows from the hydroxide thickener contained 0.2 to $0.3 \mathrm{~g} / 1$ hydroxide solids. The solids content in the hydroxide reactor ranged from 2.2 to $16.6 \mathrm{~g} / 1$, and 93 to $98 \mathrm{pct}$ of the hydroxides were removed from the slurry in the thickener. The filter cakes from the hydroxide filter press were approximately 40 pct solids. Analysis of a typical filter cake sample is shown in table 3 .

TABLE 3. - Metals analysis of typical hydroxide filter cake obtained during test 1, pct

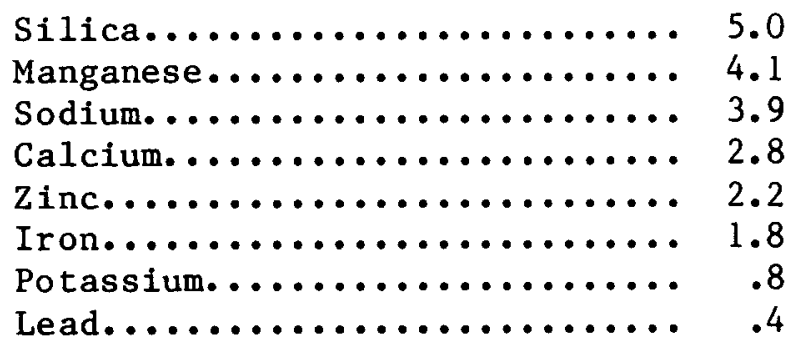

The high silica content in the filter cakes indicates that the silica reactors and thickener were undersized for removal of supersaturated silica at the operating flow rates. Analyses of silica thickener overflows and underflows showed little removal of silica.

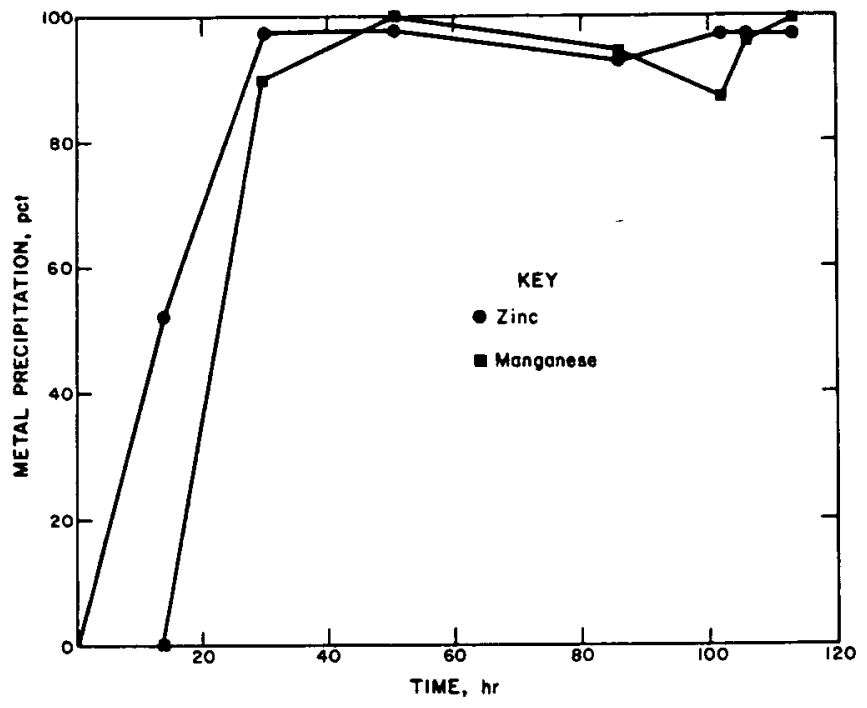

FIGURE 3. - Metals precipitation versus plant operation time: lime slurry addition with $\mathrm{pH}$ control.

$\frac{\text { Precipitation Using Set Lime Slurry }}{\text { Addition Rates (Test 2) }}$

In order to eliminate some of the problems encountered in test l, lime slurry was added at set addition rates during test 2. Four different lime addition rates were used; $21,27,35$, and $37 \mathrm{lb} / 1,000 \mathrm{gal}$ of brine. Each addition rate was maintained for $36 \mathrm{hr}$. The test series started with the lowest addition rate and increased to the highest addition rate. The lime slurry used for test 2 had a specific gravity of 1.07 (20 pct lime).

\section{Lime Addition Rates}

Percent precipitation of metals was calculated based on analyses of filtrates from the hydroxide filter press (fig. 4). The dashed lines represent the times at which the lime slurry addition rates were increased.

Lime addition rates during most of test 2 were maintained close to the designed values. In region I, lime addition rate fluctuated with occasional large, short-term variations. The average addition rate in region $I$ was approximately 10 pct less than the designed value. The peristaltic pump used to 
feed the lime slurry was operating near its minimum capacity at a lime addition rate of $21 \mathrm{lb} / 1,000$ gal of brine. Addition of lime slurry was more uniform in regions II and III with few fluctuations. Addition rates were approximately 2 pct above designed values. During operation in region $I V$, small fluctuations occurred that were between 5 pct above and below the designed value. The fluctuations were cyclic in nature so that the average addition rate was approximately 0.5 pct above the designed value.

\section{Precipitation of Dissolved Metals}

Iron analyses of filtrates from the hydroxide filter press were less than the detection limit of $0.2 \mathrm{mg} / 1$, which was more than 99-pct precipitation in all four regions. Analyses for lead were less than $2 \mathrm{mg} / \mathrm{I}$ in regions $I$ and $I I$ and varied over a wide range in regions III

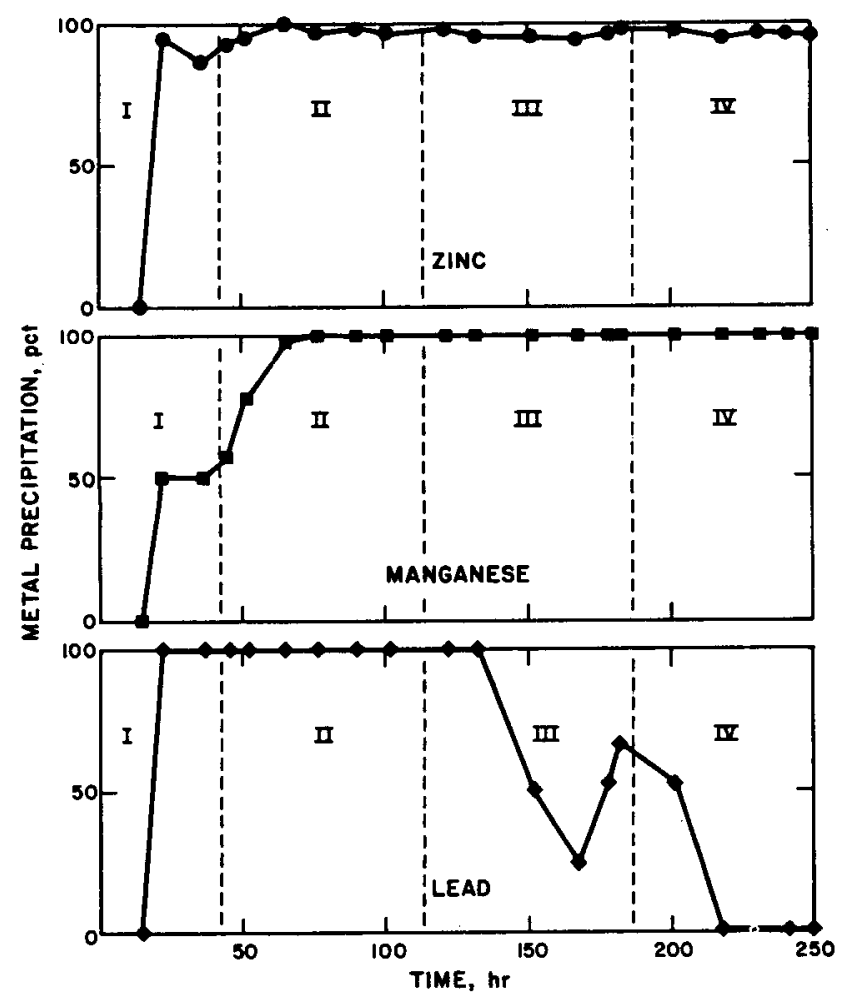

FIGURE 4. - Percent precipitation of metals at different lime addition rates versus plant operating time. Lime addition rates, in pounds per $1,000 \mathrm{gal}$ of brine for each region, were I, 21; II, 27; III, 35; IV, 37. and IV. Most of the analyses near the end of region IV showed more lead in the filtrate than was present in the feed brine. This behavior followed expected patterns because lead can be dissolved from precipitated hydroxides under the more basic conditions in regions III and IV.

In region $I$, analyses for zinc showed a rapid increase to 95-pct precipitation after $23 \mathrm{hr}$ of operation and a slight decrease to 91-pct precipitation at $38 \mathrm{hr}$. Precipitation of zinc increased to 93 pct at the end of region $I$. This type of behavior is characteristic of a system approaching steady state conditions and suggests that approximately 92 to 93 pct of the zinc can be precipitated at an addition rate of $21 \mathrm{lb}$ of lime per 1,000 gal of brine. Zinc precipitation was consistently more than 95 pct during the remainder of the test.

Analyses for manganese showed that only 50 to $58 \mathrm{pct}$ was precipitated in region I. Manganese levels in the filtrate from the hydroxide filter press decreased rapidly to less than $0.8 \mathrm{mg} / 1$ at the beginning of region II and remained at this level throughout the test. This represents more than 99-pct precipitation of manganese.

\section{$\mathrm{pH}$ Measurements}

Measurements of $\mathrm{pH}$ in the hydroxide thickener during test 2 showed the same type of fluctuations observed in test 1 , even though lime addition rates were more constant. During operation in region $I$, precipitation of manganese was incomplete even though average $\mathrm{pH}$ values were 8.5 to 9.0 . Similar $\mathrm{pH}$ readings were obtained during region II operation. The $\mathrm{pH}$ values were $\sim 10$ in regions III and IV. These data indicate that $\mathrm{pH}$ is a poor process control measurement and would only be useful as an indicator of excessive lime addition.

\section{Thickener Performance}

Measurements of total suspended solids in the precipitation reactors and 
thickener showed poor thickener efficiency in region $I$. The reactors contained 2 to $5 \mathrm{~g} / 1$ solids, while the overflow from the thickener contained $1 \mathrm{~g} / 1$ solids. Removal of solids in the thickener averaged approximately 75 pct. During region II operation, the solids in the reactors increased to 4 to $6 \mathrm{~g} / 1$ solids and the thickener overflow concentration decreased to $0.8 \mathrm{~g} / 1$ solids. This represents 80- to 87-pct removal of solids in the thickener. Efficiency of the thickener during test 2 was slightly less than was reported for test 1 when solids removal was 93 to $98 \mathrm{pct}$ and thickener overflow contained $0.2 \mathrm{~g} / 1$ solids. The only measured parameter that was different during these tests was the temperature. More insulation was added to the thickener and some of the slurry lines after test 1 and resulted in temperatures that were $20^{\circ}$ to $30^{\circ} \mathrm{F}$ higher in the thickener during test 2 .

Removal of solids increased to more than 97 pct in regions III and IV. The amount of solids in the reactors was higher during operation in these regions because of the presence of unreacted lime. The higher solids content in the slurry may account for the more efficient operation of the thickener. Overflow from the thickener contained $0.25 \mathrm{~g} / 1$ solids during region III operation and $0.75 \mathrm{~g} / 1$ solids during region IV operation.

\section{Filter Cake Compositions}

Compositions of filter cakes from the hydroxide filter press followed the expected trends. Table 4 presents the analysis of a filter cake sample taken at the end of each of the four regions. Incomplete precipitation of manganese during region $I$ operation accounts for the lower manganese value. Similarly, the lower value for lead in the sample from region IV demonstrates the redissolution of lead when excess lime is added. The steady decrease in iron and $z$ inc analyses is due to dilution of the filter cake by unreacted lime in regions III and IV, and by increased manganese precipitation in region II.

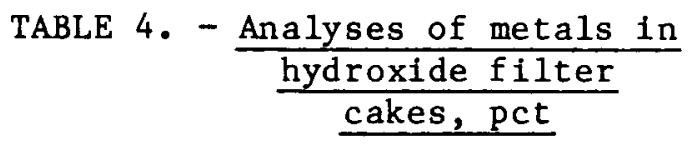

\begin{tabular}{|c|c|c|c|c|}
\hline & $\mathrm{Mn}$ & $\mathrm{Fe}$ & $\overline{\mathrm{Zn}}$ & $\mathrm{Pb}$ \\
\hline Region I..... & 3.1 & 2.7 & 2.1 & $\overline{0.3}$ \\
\hline Region II.... & 4.4 & 1.3 & 1.8 & .3 \\
\hline Region III... & 3.2 & .9 & 1.2 & .1 \\
\hline Region IV.... & 2.0 & .6 & .8 & .06 \\
\hline
\end{tabular}

Silica Removal

In an attempt to improve the silica removal reported for test 1 , the silica thickener was modified prior to the start of test 2. The modifications altered the slurry feed line so that incoming slurry would not create turbulence in the thickened slurry. To monitor silica removal, an extra set of samples was taken from the silica reactors, silica thickeners, and silica filter press during test 2 . The samples were diluted 20 to 1 and acidified to avoid precipitation before analysis. When the samples were analyzed, most of them contained precipitated silica, even the filtrates from the silica filter press taken near the end of test 2. These observations indicated that the modifications made on the silica thickeners were insufficient to accomplish silica removal.

\section{Precipitation Using

Dry Lime (Test 3)

Test 3 employed addition of dry lime instead of a lime slurry. The lime was added to the first hydroxide reactor tank with an auger screw fed from a hopper. A vibrator was attached to the hopper to minimize packing of the lime, which would cause irregular or "plug" flow. This arrangement was only partially successful in maintaining a steady lime addition rate.

Analysis of filtrates from the hydroxide filter press showed that more than 99 pct of the iron and manganese were precipitated during test 3 . Precipitation of zinc ranged from 94 to 99 pct, with an average value of 96 pct. In contrast, analyses for lead varied over a wide range with no detectable 
trend. In many samples, more lead was found in the filtrate than in the feed brine.

To determine whether the high lead values were due to analytical error, samples of slurry obtained from the hydroxide reactors and thickener overflow and underflow were filtered and the filtrates analyzed for lead. These analyses were compared with samples of the filtrate from the hydroxide filter press. The analyses of samples taken at a given time should show negligible differences. The results of this verification procedure showed that the sample analyses were very different from one another. As an example, one sample set showed $10 \mathrm{mg} / 1 \mathrm{~Pb}$ in the reactor filtrate, $20 \mathrm{mg} / 1$ in the underflow filtrate, $30 \mathrm{mg} / 1$ in the overflow filtrate, and $100 \mathrm{mg} / 1$ in the filter press filtrate. The behavior suggested that unreacted lime was present in the solid portion of the slurry and resulted in localized high $\mathrm{pH}$ values and redissolution of lead.

Results obtained from the hydroxide thickener during test 3 were similar to those obtained when an equivalent amount of lime slurry was used. The hydroxide reactor tanks contained 6 grams of suspended solids per liter compared with 4 to $5 \mathrm{~g} / 1$ solids using lime slurry. The overflow from the hydroxide thickener contained 0.6 to $0.9 \mathrm{~g} / 1$ solids. This represents 85 - to 90 -pct removal of solids in the thickener and is the same removal obtained using lime slurry.

Since 10 to 15 pct of the slurry solids were not recovered by thickening, samples of solids from the reactors, thickener underflow, and thickener overflow were analyzed to determine whether there was any variation in composition. A typical analysis of the solids is shown in table 5. The samples were prepared by filtering the solids from the slurry sample, washing with water, and drying at $100^{\circ} \mathrm{C}$. The dried solids were dissolved in hydrochloric acid and analyzed by atomic absorption spectrophotometry. Acid-insoluble residues were dried and weighed. Emission spectroscopy showed that the major component of the insoluble residue was silica. The data in table 5 show that the composition of the solids in the flow streams in and out of the thickener are not the same. The thickener overflow stream was enriched in manganese by a factor of 2.5 compared to iron, and zinc was enriched by a factor of 1.3 compared to iron over the values measured in the reactor. Solids lost in the thickener overflow represent a larger percentage loss of manganese and zinc from the system than is apparent from the solids concentrations in the flow streams. These results demonstrate that the solids filtered from the thickener underflow will contain slightly less manganese and zinc compared to the composite brine. This is verified by the comparison of metal value ratios in table 6 .

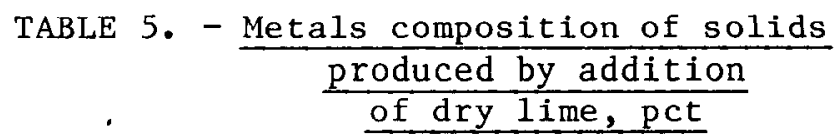

\begin{tabular}{l|l|l|l|l}
\hline & Mn & Zn & Fe & Pb \\
\hline Fourth reactor..... & 17 & 8.0 & 6.3 & 1.3 \\
Thickener overflow. & 18 & 4.5 & 2.7 & 1.2 \\
Thickener underflow & 12 & 5.4 & 4.7 & .8 \\
\hline
\end{tabular}

TABLE 6. - Metal concentration ratios

\begin{tabular}{|c|c|c|}
\hline Sample & $\mathrm{Mn} / \mathrm{Fe}$ & $\mathrm{Zn} / \mathrm{Fe}$ \\
\hline $\begin{array}{l}\text { Average brine......... } \\
\text { Filtered hydroxides: }\end{array}$ & 4.35 & 2.66 \\
\hline Test $1 \ldots . . .$. & 2.29 & 1.21 \\
\hline Test 2.... & 3.38 & 2.44 \\
\hline Test 3....... & 2.38 & 1.97 \\
\hline Test $4 \ldots \ldots$..... & 3.17 & 1.33 \\
\hline
\end{tabular}
in brine and filtered hydroxides

Precipitation Using Lime Slurry With Air Injection (Test 4)

Test 4 was carried out using lime slurry and air injection to determine the effect of oxidation on recovery of metal values. A manifold was used to supply a total of $6 \mathrm{ft}^{3} / \mathrm{min}$ of air to the four hydroxide reactor tanks. Precipitation of metal values determined from filtrates from the hydroxide filter press was very good. During portions of the test, metal values in the filtrate were less 
than analytical detection limits. The detection limits yielded 99-pct precipitation of iron and manganese, 97-pct precipitation of zinc, and 83-pct precipitation of lead. Correlation of $\mathrm{pH}$ readings with lime addition rates was the best obtained during this study. These data suggest that part of the difficulty in obtaining reproducible $\mathrm{pH}$ readings is caused by changing oxidation states and is not entirely due to coating of the electrodes.

The $\mathrm{pH}$ readings in the hydroxide thickener were less than 9.0 after the first $14 \mathrm{hr}$ of operation and decreased below 8 for two short periods. Each time the $\mathrm{pH}$ decreased below 8, precipitation of metal values decreased by 5 to $10 \mathrm{pct}$ during the next $8 \mathrm{hr}$. When the $\mathrm{pH}$ increased above 8 , precipitation of metal values increased.

Evaluation of samples taken from the hydroxide thickener showed that air injection did not affect the recovery of metal hydroxides. Overflows from the thickener contained 0.2 to $0.5 \mathrm{~g} / 1$ solids and indicated 81 - to 90-pct recovery of solids in the thickener. As in earlier tests, the solids in the overflow samples were slightly enriched in manganese and zinc when compared with the solids in the hydroxide reactors. Temperatures measured in the thickener ranged from $110^{\circ}$ to $135^{\circ} \mathrm{F}$, and recovery of solids decreased from $89 \mathrm{pct}$ at $110^{\circ} \mathrm{F}$ to $81 \mathrm{pct}$ at $135^{\circ} \mathrm{F}$. Composition of the filter cakes was similar to the values reported in table 3 and region II of table 4.

\section{Precipitation Using Lime Slurry With Exclusion of Air (Test 5)}

During test 5, the effect of excluding air was investigated. Covers were placed on all of the tanks to trap a layer of steam that excluded air from the system. Evaluation of samples taken during the test indicated that the system was operating under non-steady-state conditions. Measurements of $\mathrm{pH}$ showed no trend and could not be correlated to lime addition rates. Analyses of filtrates from the hydroxide filter press varied over a wide range with no trend. Ana1ysis of the liquid portion of the samples taken from the hydroxide reactor and thickener underflow showed no agreement either with one another or with samples of the filter press filtrate taken within $0.5 \mathrm{hr}$ of the previous sample.

Since the MRU never obtained steady state conditions during the test, no evaluations were made on samples from the hydroxide thickener or filter press.

\section{Recovery of Metal Values From Hydroxide Precipitates}

In conjunction with operation of the MRU to precipitate metal values from the brine, laboratory experiments were conducted to investigate the recovery of metals from the hydroxide filter cakes. A hydroxide precipitate was prepared by treating several hundred gallons of postflash brine with lime slurry. The precipitate was filtered in a centrifuge and analyzed (table 7). Comparison of the filter cake with those obtained at the MRU (see table 3 ) shows that it contains less metals and more salts. With the exception that the filter cake prepared for recovery studies contains a larger amount of entrained brine, it is very similar to those produced at the MRU.

TABLE 7. - $\frac{\text { Metals analysis of hydroxide }}{\frac{\text { filter cake prepared for }}{\text { recovery studies, pct }}}$

Sodium.................... 4.3

Manganese................... 3.4

Calcium................... 2.7

Zinc..................... 1.2

Iron..................... 1.1

Potassium.................. .9

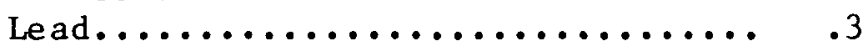

The potential value of the metals precipitated from the brine is shown in table 8. Since the major dollar value contained in the precipitates is represented by the zinc, the laboratory study was directed toward selective leaching of zinc from the filter cake. Coleaching of lead was acceptable, but leaching of iron or manganese was not desirable. The most 
obvious method for achieving this goal would be to use a basic leachant. Experiments were designed for leaching with solutions of $\mathrm{NaOH}, \mathrm{NH}_{4} \mathrm{OH}$, and $\mathrm{NH}_{4} \mathrm{Cl}$.

Contacting the filter cake with solutions containing 25 to 50 pct $\mathrm{NaOH}$ resulted in a viscous slurry that was difficult to filter. With $\mathrm{NaOH}$ leaching the best extractions were 44 pct of the zinc, $28 \mathrm{pct}$ of the lead, and 2 pct each of iron and manganese. Leaching with solutions of $\mathrm{NH}_{4} \mathrm{OH}$, was selective for zinc, but only 35 to 42 pct of the zinc was leached. There was no detectable leaching of iron or lead, and leaching of manganese was less than 1 pct. Releaching of tailings resulted in a slight increase in zinc recovery. Leaching with $\mathrm{NH}_{4} \mathrm{Cl}$ yielded results similar to leaching with $\mathrm{NH}_{4} \mathrm{OH}$. Modifying the leaching conditions by purging with air or by leaching at $96^{\circ} \mathrm{C}$ gave no improvement.

TABLE 8. - Gross value of metals precipitated from post-flash brines

\begin{tabular}{c|c|c}
\hline Metal & $\begin{array}{c}\text { Concentration in } \\
\text { brine, mg/1 }\end{array}$ & $\begin{array}{c}\text { Gross values, } \\
\$ / 1,000 \text { gal }\end{array}$ \\
\hline Zinc..... & 270 & 0.91 \\
Lead..... & 50 & .11 \\
Iron..... & 160 & .01 \\
Manganese & 710 & .01 \\
\hline
\end{tabular}

Since zinc recoveries were less than 50 pct with basic leaching systems, an investigation into selective leaching with acids was initiated. Leaching with increasing strengths of $\mathrm{HCl}$ extracted manganese most readily. When 20 pct of the manganese was leached, zinc began to dissolve and then iron and lead as the solution became more acidic. Attempts to suppress manganese by using oxidizing conditions were only partially successful. Leaching tests at $96^{\circ} \mathrm{C}$ or with an air purge gave little improvement. Leaching with a chlorine gas purge resulted in extraction of 91-pct of the zinc, 40 pct of the manganese, 46 pct of the lead, and $35 \mathrm{pct}$ of the iron. The best result was obtained using an ozone purge with $4.5 \mathrm{ml}$ of concentrated $\mathrm{HCl}$ and $50 \mathrm{ml}$ of $\mathrm{H}_{2} \mathrm{O}$ to leach 50 grams of filter cake. The combined leaching and washing solutions contained 99 pct of the zinc, 23 pct of the manganese, 15 pct of the lead, and 2 pct of the iron. Experiments using dilute $\mathrm{H}_{2} \mathrm{SO}_{4}$ were only successful in separating zinc from lead. Iron and manganese leached as well, or better, than zinc.

A survey of stability constants for iron, manganese, zinc, and lead with complexing agents was made. The complexing agents considered were oxalic acid, EDTA, DTPA, hydroxide ion, citric acid, and lactic acid. Evaluation of literature values for the complexing agents suggested a high degree of selectivity for zinc over iron and manganese using EDTA at a neutral or basic pH. Leaching tests using hydroxide filter cake resulted in 51-pct extraction of zinc and 13-pct extraction of manganese. These values did not improve when the filter cake was washed with water to remove calcium before leaching, thus avoiding competition for EDTA. Experiments were also conducted using sodium oxalate in an ammoniacal solution (5). Zinc was selectively leached with this solution, but the best results yielded extraction of 40 pct for zinc and 1.5 pct for manganese. These results offered no improvement over using ammonia.

\section{DISCUSSION AND CONCLUSIONS}

Precipitation of metal values during operation of the MRU agreed with the results predicted by an engineering study. The use of $27 \mathrm{lb}$ of lime per $1,000 \mathrm{gal}$ of brine resulted in 95- to 99-pct precipitation of iron, manganese, zinc, and lead. Lower lime additions were insufficient for complete precipitation of manganese, and higher lime additions caused redissolution of lead. Adding lime as a 15- to 20-pct slurry was preferred to adding dry lime because dry lime agglomerated on contact with the brine. Only a portion of the dry 
lime was available for precipitation of metal values. Localized high $\mathrm{pH}$ resulted in the slurries and filter cakes and caused redissolution of lead. Injection of air had no detectable effect on precipitation of metal values, whereas exclusion of air resulted in non-steadystate conditions.

Addition of lime slurry to the brine was best controlled by using fixed, precalculated addition rates. The use of $\mathrm{pH}$ measurements to control lime addition was unsatisfactory because of the difficulty in obtaining reliable $\mathrm{pH}$ readings. The high temperature and salinity of the brine create an unfavorable environment for most $\mathrm{pH}$ electrodes. Electrodes becoming coated with lime or metal hydroxides further complicated the measurements. The $\mathrm{pH}$ measured during the tests employing air injection and exclusion of air suggests that oxidation rate of the metals may also affect $\mathrm{pH}$ measurements. While methods of measuring $\mathrm{pH}$ were not specifically investigated during operation of the MRU, the data suggest that $\mathrm{pH}$ could be used as a process control measurement if appropriate self-cleaning electrodes are used under sufficiently oxidizing conditions.

Rake classifiers were ineffective for silica removal prior to precipitation of metal values. Increasing the solids concentration in the slurries improved silica removal. Lower operating temperatures may also have been beneficial, but would not be compatible with the energy recovery circuit. Potentially, a more effective method of silica removal would employ a reactor-clarifier in place of the rake classifier. The resultant sludge blanket that develops in a reactor-clarifier decreases silica content to saturation levels (49 mg/1).

Removal of metals as hydroxides with the modified rake classifier was 80 to 90 pct. Higher solids content in the hydroxide reactor resulted in decreasing solids content in the thickener overflow. Lower temperatures in the thickener produced similar results. The effect of lower temperature within the thickener was probably due to decreased temperature gradients, which resulted in decreased disturbance of thickening sludge by thermal currents. Analysis of the composition of the solids in the thickener overflow showed that the solids were enriched in manganese and $z i n c$ with respect to iron. These results were verified by analysis of filter cakes taken from the hydroxide filter press. This behavior represents a dilution of the recovered metal values with a lower value metal. Improved thickening of hydroxide slurries by better thickener design and/or better insulation to minimize thermal mixing is desirable. A reactor-clarifier might improve hydroxide recovery in the same manner in which silica removal could be improved.

The major weakness discovered in the metal value recovery system was treatment of hydroxide filter cakes. The highest metal value was zinc; attempts to separate zinc from iron and manganese were partially successful. Leaching with $\mathrm{NH}_{4} \mathrm{OH}$ was selective for zinc, but only 42 pct of the zinc was leached. Releaching of treated hydroxides resulted in an additional recovery of $<10$ pct and suggested that more than one species of $z$ inc compound was present in the filter cakes. Selective leaching under acidic conditions was effective when the leaching was done under strong oxidizing conditions. Hydrochloric acid and ozone leached 99 pct of the zinc, 23 pct of the manganese, 15 pct of the lead, and 2 pct of the iron. The pregnant solution contained equal amounts of $z i n c$ and manganese. Use of complexing agents resulted in no improvement in zinc extraction.

Since the brines represent a low grade source of metal values, recovery of 50 pct of the values is not satisfactory. Results of a contract study (4) carried out at the same time the $M \bar{R} U$ was operating show that high recovery of zinc and lead may be obtained by treating the brines with $\mathrm{Na}_{2} \mathrm{~S}$ solutions. Since zinc and lead are precipitated preferentially to iron and manganese, precipitation of the latter two metals may be minimized by controlling the quantity of 
sulfide addition. This would result in precipitation of a higher value product than is possible with lime addition. A preferred processing scheme would employ $\mathrm{Na}_{2} \mathrm{~S}$ to precipitate zinc and lead followed by lime addition to precipitate iron and manganese. Data obtained during operation of the MRU can be applied to the lime precipitation of iron and manganese.

\section{REFERENCES}

1. Berthold, C. E., P. Hadzeriga, D. H. Christopher, T. A. Applegate, and D. M. Gillespie. Process Technology for Recovering Geotherma1 Brine Minerals. BuMines OFR 35-75, 1975, 255 pp.; National Technical Information Service, Springfield, Va., PB $241867 /$ AS.

2. Berthold, C. E., and F. M. Stephens. Magmamax No. 1 Geothermal Brine Bulk Solids Precipitation Pilot PlantEngineering Design. BuMines OFR 127-78, 1978, 84 pp.

3. Christopher, D. H., Maxine Stewart, and Janet Rice. The Recovery and Separation of Mineral Values From Geothermal Brines. BuMines OFR 81-75, 1975, 43 pp.; National Technical Information Service, Springfield, Va., PB 245 686/AS.

4. Farley, E. P., E. L. Watson, D. D. MacDonald, R. W. Bartlett, and G. N. Krishnan. Recovery of Heavy Metals From High Salinity Geothermal Brines. BuMines OFR 91-81, 1981, $130 \mathrm{pp}$; $\mathrm{Na}-$ tional Technical Information Services, Springfield, Va., PB 81-222218.

5. Gornicki, J., and Z. Jablonski. Mechanism of Dissolution Process of Zinc
Oxalate in Ammonia Solutions. Roczniki Chemii, Ann. Soc. Chim. Polonorum, v. 47, No. 1985, 1973, 7 pp.

6. Sanders, J. W., and M. J. Mi11s. Mineral Content of Selected Geothermal Waters. BuMines OFR 14-75, 1975, 37 p p.; National Technical Information Services, Springfield, Va., PB 240 419/AS.

7. San Diego Gas and Electric. Geothermal Loop Experimental Facility--Final Report, April 1980; National Technical Information Service, Springfield, Va., DOE-ET-28443-T1.

8. Tippin, R. B., and P. E. Mueh1berg. Chemicals From Brines. Ch. in Encyclopedia of Chemical Technology, ed. by M. Grayson, John Wiley \& Sons, New York, 3d ed., v. 5, 1979, pp. 375-393.

9. Urbanek, M. W., C. D. Hornberg, and $\mathrm{B}$. Lindal. Research on a Geothermal Mineral Extraction Complex. Phase 1. Preliminary Technical and Economic Assessment. BuMines OFR 51-79, 1979, $194 \mathrm{pp}$. 